\title{
Reforming Practice or Modifying Reforms?: Elementary Teachers' Response to the Tools of Reform
}

\author{
Leigh K. Smith, ${ }^{1}$ Sherry A. Southerland ${ }^{2}$ \\ ${ }^{1}$ Department of Teacher Education, Brigham Young University, \\ 206-P McKay Building, Provo, Utah 84602 \\ ${ }^{2}$ Department of Middle \& Secondary Education, Florida State University, \\ Tallahassee, Florida 32306-4490
}

Received 16 February 2005; Accepted 27 June 2006

\begin{abstract}
Understanding the interaction between internally constructed and externally imposed aspects of the teaching context may be the missing link between calls for school reform and teachers' interpretation and implementation of that reform. Although the context of the local school culture has a profound impact on teachers, there are other external forces that are specifically aimed at influencing teachers' pedagogical and curricular decisions. These externally imposed aspects of context include some of the existing tools of reform, such as national standards, mandated state core curricula, and related criterion-referenced testing. However, little is known about how these reform tools impact teachers' thinking about science and science teaching or how teachers respond to such tools. This study examined the interactions between individual teachers' beliefs about teaching and learning science in elementary school and the tools of reform that are imposed upon them. Comparative case studies were conducted in which two elementary teachers' science instruction, teaching context, and related beliefs were examined, described, and analyzed. In this study, the teachers' fundamental beliefs about science and what it means to teach and learn science influenced their interpretations of the sometimes contradictory messages of reform as they are represented in the standards, mandated curriculum, and end-of-level tests. Suggestions about what these findings mean for needed aspects of teacher professional development are offered. (c) 2007 Wiley Periodicals, Inc. J Res Sci Teach 44: 396-423, 2007
\end{abstract}

Attempt at large-scale educational reform in the United States has typically been top-down, legislated, and mandated by the courts, and/or sponsored and promoted by government agencies or other special interest groups or organizations (DeBoer, 1991; Duschl, 1990; Sarason, 1996). These calls for change within schools have primarily come from outside the public school system, and are usually disseminated through policy reports and other publications that outline or prescribe specific programs, practices, and curricula. More recently, educational restructuring

Correspondence to: L.K. Smith; E-mail: leigh_smith@byu.edu

DOI 10.1002/tea.20165

Published online in Wiley InterScience (www.interscience.wiley.com). 
efforts have also been tied to documents published in cooperation with professional organizations that describe national standards specific to individual academic disciplines. These initiatives advance principles intended to improve teaching, teacher development, content, programs, and systems (e.g., International Reading Association [IRA], 2004; National Council of Teachers of Mathematics [NCTM], 2000; National Research Council [NRC], 1996).

The intent of educational reform has ultimately been to improve teaching and learning within individual institutions and inside individual classrooms (Duke, 2004). However, reform initiatives historically have often failed to account for the impact of unique situations within specific classrooms, classrooms that are found deep within the multiple complex layers of the overall school system (Fullan \& Stiegelbauer, 1991; Sarason, 1996; Windschitl, 2002). Indeed, despite evidence that effective school change and new program implementation is more dependent on local elements within particular contexts (e.g., the classroom teacher, school administrative support, available resources, etc.) than on federal mandates or other top-down methods of promotion, reform efforts have traditionally neglected or undervalued the effects of such factors (McLaughlin, 1976, 1990). Until recently, the influence of particular institutional contexts and the role of individual classroom teachers (arguably the most critical layer of the school system in terms of efforts to change what happens in schools) have been disregarded (Battista, 1994; Cuban, 1990; Yee \& Kirst, 1994). Scholars now recognize, however, that ignoring the role of teachers in the process of change is likely to doom reform efforts to failure (Sarason, 1996). Consequently, the current round of national science education reform is more specifically focused on practicing teachers than past efforts to change science instruction (DeBoer, 1991; Yager, 1992).

It is important to note that some scholars suggest that the current effort to restructure science education has been in progress for some time, as it was initiated in response to a 2-day gathering of politicians, scientists, educators, and business and industrial leaders held at the National Academy of Sciences and Engineering in 1982 (Duschl, 1990). Beginning with this initial conceptualization, the efforts to begin and sustain reform have been broad in scope, promoting change via general reform documents that outline content and teaching standards (American Association for the Advancement of Science [AAAS], 1990, 1993; NRC, 1996), and through other reform tools designed to support reform efforts at both the national and local levels. Nationally, such tools as curriculum models, instructional resources and materials, assessment models, and so forth have been designed to support and encourage educators to make changes within their individual contexts (Atkin \& Black, 2003). Additionally, there is evidence that state departments of education and local school districts are making efforts to align their core science curricula and associated testing with the tenets of reform efforts (e.g., Utah State Office of Education [USOE], 1994, 2002). Corresponding professional development opportunities are also being offered, introducing new ways of thinking about science and science instruction and supporting change over time, as suggested by reformers (Bybee, 1997; Loucks-Horsley et al., 1990). The intent has been that these local tools, in combination with national standards documents, would help teachers implement reform-based instruction in their classrooms.

Despite increased efforts to concentrate on classroom teachers in the change process, however, results of these efforts are far from uniform. Research indicates that some teachers are openly embracing reform-oriented practices (Crawford, 2000), while others are either unable or unwilling to modify their curriculum or instruction to align more closely with current science initiatives (Davis, 2003; Laplante, 1997; Yerrick, Parke, \& Nugent, 1997). Clearly, the success of reform efforts at the classroom level remains mixed and researchers have offered a variety of explanations. For example, some literature suggests that specific institutional characteristics (e.g., the level of administrative support, school climate, student response, available physical space or instructional materials, and academic time devoted to teaching science) have a significant impact 
on teachers' ability or inclination to change their practice (Lynch, 2000; Raizen \& Michelsohn, 1994; Schwartz, Abd-El-Khalick, \& Lederman, 1999; Tilgner, 1990; Vesilind \& Jones, 1998). Additionally, studies indicate that individual teacher characteristics or propensities (e.g., variations in subject matter knowledge, teaching self-efficacy, or willingness to accept the risks associated with change) also influence the process of change and, therefore, the success of reform efforts within individual classrooms (Gess-Newsome, 1999).

Of note, the findings on the success of science reform are similar to those cited by mathematics education researchers (Cohen \& Ball, 1990) as well as researchers on teacher thinking (Little, 1992; Sprinthall, Reiman, \& Thies-Sprinthall, 1996). Still other educational research focuses on the complexity of changing teachers' thinking (beliefs and knowledge) to alter practice. These studies have been conducted within various content areas, including science and mathematics education, and similarly suggest that the effectiveness of reform efforts are largely dependent on teachers' ability or inability to modify their fundamental or central beliefs about what it means to teach and to learn. These are the beliefs that shape who they are as teachers and, therefore, their instructional decisions (Battista, 1994; Haney, Czerniak, \& Lumpe, 1996; Haney \& Lumpe, 1995; Haney \& McArthur, 2002; Laplante, 1997; Smith, 2005).

Much of the research to this point has emphasized the complexity of reform (see Fullan, 1993). Numerous studies have identified and debated a multitude of personal and institutional factors that influence teachers' ability or inclination to engage in reform-oriented practice. What seems to be missing, however, is careful attention to the impact that specific reform tools have on teachers' interpretation and implementation of reform. It is unclear whether the tools designed to support and enact reform facilitate this process or whether they might actually serve as barriers to change. This paper examines how three of these reform tools impact teachers' thinking about teaching and learning science. Our aim here is to describe two elementary teachers' response to common reform tools (national science standards, state science core curriculum, and related end-of-level assessment) and the role of these tools in shaping or modifying classroom practice.

\section{Theoretical Framework}

\section{Beliefs and Reform}

A good deal of research has been published on the beliefs that teachers hold about teaching and learning and the impact that these beliefs have on what happens in classrooms. Generally, scholars agree that these beliefs are inextricably intertwined with teachers' subject matter knowledge and understanding of instruction (Alexander \& Dochy, 1995; Gess-Newsome, 1999). Moreover, beliefs are understood to be derived from a multitude of experiences within formal and informal teaching/learning contexts both in schools (Holt-Reynolds, 1992) and out of schools (Smith, 2005). Described as "orientations" toward teaching (Calderhead \& Robson, 1991, p. 1), researchers note that teachers' beliefs or personal theories about teaching and learning inform the decisions they make concerning teaching methods and strategies as well as the information they choose to share with children (Battista, 1994; Brickhouse \& Bodner, 1992; Laplante, 1997; Smith, 2005). Indeed, a substantial body of literature suggests that the way teachers interpret and implement curricula is significantly influenced by their subject matter beliefs (Gregoire, 2003) in combination with their notions about how specific content should be taught (Czerniak, Lumpe, \& Haney, 1999; Gess-Newsome, 1999; Lumpe, Haney, \& Czerniak, 1998a,b; Thompson, 1992). In short, the general consensus is that teachers possess well-developed personal theories of professional practice, or "personal practice theories" (see Cornett, Yeotis, \& Terwilliger, 1990), that guide their practice (Sweeney, Bula, \& Cornett, 2001). 
The relationship between personal practice theories and the actions that are tied to these beliefs is critical to our understanding of efforts to reform schools and schooling (Battista, 1994; Cuban, 1990; Gregoire, 2003). Because teachers' beliefs serve as guides to subsequent actions in the classroom (Clark \& Peterson, 1986; Cooney \& Shealy, 1997; Thompson, 1992), educational reform is largely dependent on teachers' ability to think differently about learning and instruction (Putnam, Heaton, Prawat, \& Remillard, 1992). Therefore, changing beliefs is thought to be prerequisite to long-term, sustained change in practice (Richardson, 1996).

Modifying teachers' beliefs, however, is a complex endeavor. Beliefs about teaching and learning are well established by the time an individual enters college and are profoundly resistant to change, particularly during adulthood (Pajares, 1992). Moreover, because teachers invest emotionally and intellectually in their beliefs (as do all humans), they seek to maintain them unless these beliefs are sufficiently challenged and the individual is "unable to assimilate them into existing conceptions" (Pajares, 1992, p. 321). As a result, teachers "have variously welcomed, improved, deflected, coopted, modified, and sabotaged outside efforts at reform" (Tyack \& Cuban, 1995, p. 7). Retaining a fair degree of autonomy, "[O]nce the classroom door [is] closed, [teachers can], if they [choose], comply only symbolically or fitfully or not at all with the mandates for change pressed on them by platoons of outside reformers" (Tyack \& Cuban, 1995, p. 9). It is possible, then, that teachers intentionally or unintentionally alter reforms more frequently than intended reforms change what happens in their classrooms. Because of this, teachers have been identified as "the root of the problem" in failed efforts at reform (Cohen \& Ball, 1990, p. 233). At the same time, teachers are also recognized to be the "key agents" of change (Cohen \& Ball, 1990, p. 233) because it is ultimately the classroom teacher who bears the responsibility for implementing reforms (Bybee, 1993, p. 233).

Recognizing that teachers and their beliefs or personal theories play a fundamental role in mediating educational change, multiple studies have focused on understanding the relationship between beliefs and subject-matter reform efforts. Not surprisingly, this research suggests that what teachers believe about proposed change influences the outcome of reform efforts (Gregoire, 2003; Sarason, 1996). The evidence is that teachers' beliefs either facilitate or interfere with successful reform implementation (Cronin-Jones, 1991; Lumpe et al., 1998a,b). Although some teachers openly embrace specific aspects of reform, others are not prepared or inclined to enact change. For example, there is evidence that deeply held subject-matter beliefs constrain contentarea teachers (such as science and mathematics educators) from adopting practices that conflict with their notions of what is appropriate curriculum and instruction (Fennema \& Franke, 1992; Franke, Carpenter, Fennema, Ansell, \& Behrend, 1998; Laplante, 1997). In some cases, teachers' conceptions of specific subject matter and content instruction are completely incongruous with those of policy makers or reformers (Abell \& Smith, 1994; Cronin-Jones, 1991; Lederman, 1992; Southerland, Gess-Newsome, \& Johnston, 2003). As a result, teachers' personal theories block "their understanding and acceptance of the reform movement, thereby precluding the possibility of substantive curricular [and pedagogical] change" (Battista, 1994, p. 467).

Other studies suggest that preexisting subject matter beliefs and personal practice theories also affect how reforms are implemented (Borko, Davinroy, Bliem, \& Cumbo, 2000; Laplante, 1997). In effect, teachers' convictions about the nature of learning and the purpose of teaching alter the reform messages as teachers filter these new ideas through their existing belief structures (Pajares, 1992). Teachers then assimilate these modified messages into what they already believe about teaching and learning rather than revising their preexisting beliefs. Thus, even well-meaning teachers who maintain that they value proposed changes and believe they are embracing radically new practices may not implement reforms as intended by reformers (Gess-Newsome, Southerland, Johnston, \& Woodbury, 2003; Gregoire, 2003; Southerland et al., 2003). 


\section{Beliefs, Context, and Reform}

Although it is evident that teachers' beliefs impact the implementation of reforms, it is unclear as to what attendant conditions-what contextual issues or forces-are likely to challenge beliefs enough to facilitate change. On the other hand, it is equally unclear as to what issues of context may serve to constrain teachers' efforts or abilities to implement reform. Attempts to identify these circumstances, forces, or experiences have led researchers to focus on the interactions between beliefs and practice and the multiple contextual factors that interact with them. A number of scholars now suggest that the contexts within which teachers live and work have a potentially powerful impact on teachers' personal theories about both content and pedagogy and ultimately shape teaching practices (Bullough \& Baughman, 1997; Lumpe, Haney, \& Czerniak, 2000). The claim is that various aspects of the teaching context impact teachers' thinking about instruction, a notion that is particularly important as researchers strive to identify contextual barriers to national efforts to help teachers modify their beliefs and transform their practice.

The notion of what is meant by context and what factors are considered contextual, however, is not universally understood. Context is conceptualized differently depending on the theoretical lens through which it is viewed. Conventionally, it has been described simply as a "static, residual, surrounding "container' for social interaction" (Lave, 1993. p. 22), which neither influences nor is impacted by the individuals or the activity that is held within it. As such, context is usually equated with physical location or setting. From this perspective, a teaching context would be the classroom or school wherein a teacher works. A broader conception of context, however, suggests that it includes the social exchanges that occur within different physical environments and the features of those settings that influence interactions (Lave, 1991). Thus, the contextual factors that are likely

to influence beliefs and reform of teaching would include the environmental circumstances and the personal interactions that support or limit teachers' ability or proclivity to teach in certain ways (Bullough \& Baughman, 1997; Firestone \& Louis, 1999; Fullan \& Stiegelbauer, 1991; Gregoire, 2003; Hargreaves, 1994; Sarason, 1996). These factors "include the conditions of the classroom; the educational emphases of the school; the political, social and educational relationship between the school and the community; the financial resources available; the educational policies that govern teaching, and so on" (Jones, 1997, p. 132).

Warren (1987), however, extends this view of context even further. He includes a school culture's norms, expectations, mechanisms for determining what is and is not acceptable in given situations, and the ways in which a person forms his or her identity as contextual features. Through this situated lens (see also Lave, 1993), context is understood to be intertwined with perspectives and includes the methodology a teacher utilizes, his or her instructional goals, and his or her beliefs and knowledge about subject matter and its relationship to what is appropriate or inappropriate to do with students. The teaching context, then, includes the ways teachers interact with environmental structures or situations within the school. In this way, teachers are not merely "victims of context" (Jones, 1997, p. 133); rather, they are able to frame and give meaning to their actions, ideas, and experiences. As a result, teachers are likely to influence the context of their practice as much as other aspects of that context impact what teachers think and what they do (Gess-Newsome et al., 2003). According to this perspective, there is a dynamic relationship between the externally imposed and the internally constructed faces of context. Jones (1997) explains,

Although setting, policy, and conditions may be imposed principally by external forces, they are not unaffected by a teacher's goals and perspective.... Similarly, although teachers' goals, beliefs, and perspectives are fundamentally internally constructed, they are definitely affected by conditions and policies. (p. 134) 
There are a number of external forces that are specifically aimed at influencing teachers' knowledge and beliefs about content and pedagogy, particularly within the current context of science education reform. These forces or particulars of teachers' instructional circumstances (contextual factors) include, among other things, some of the existing tools of reform, such as national science standards, mandated state core curricula, and related criterion-referenced testing. Although there is some evidence that state-imposed curricula and mandated assessment drive academic content presented in classrooms (Duncan, Gess-Newsome, \& Stoddart, 1993) and even how science is taught (Yerrick et al., 1997), it is not clear how these reform tools impact teachers' thinking about what it means to teach science or their inclinations to embrace reform. Additionally unclear are the ways teachers respond to these externally imposed aspects of their teaching contexts.

\section{The Study}

The research reported here was part of a comparative, multicase study (see Bogdan \& Biklen, 1998) that was designed to examine the role of different contexts and the forces within those contexts in shaping, reinforcing, or modifying the beliefs and practice of two elementary science teachers in two different settings. As a piece of this in-depth investigation of the beliefs and practice of these teachers, this article focuses specifically on the interactions between these teachers' beliefs and particular externally imposed contextual factors within the context of their teaching science to elementary children. Our goal here was to describe how the two elementary teachers responded to specific reform tools designed to change teachers' thinking about science and science instruction (national science standards, state-mandated science curricula, and associated criterion-referenced testing). In this research we characterized how these tools were perceived by the teachers and how the tools ultimately impacted what happened in their classrooms.

The complexity of describing contexts and interpreting and inferring individual teachers' beliefs necessitated a qualitative, interpretive research methodology (Peshkin, 2000). This research perspective assumes that researchers build meaningful generalizations from detailed understandings of specific contexts (Jacob, 1992). Therefore, comparative case studies of two participating elementary teachers were constructed (Gall, Gall, \& Borg, 2003) using multiple data sources. This was done to provide a rich description of the teaching contexts of the participants and to enable us to make inferences concerning their beliefs about science teaching and learning.

\section{Participants}

Selection Process. The intention of the study was to examine the impact of specific aspects of teachers' science teaching contexts and this intention shaped the selection of the two participants. We recognized that multiple experiences and forces throughout individuals' lives potentially shape beliefs about academic content as well as teaching and learning (Holt-Reynolds, 1992; Smith, 2005). Therefore, one of our goals during the selection process was to limit some of the possible differences in beliefs and practice that might have been introduced through obvious disparities in participants' current teaching contexts and their past science-related experiences in schools or schooling. After all, it is well-recognized that these are experiences that potentially shape the beliefs and practice of teachers (Lortie, 1975). To accomplish this, we developed a questionnaire that was used to purposefully select participants from a population of nearly 1,200 
elementary teachers within a large, predominantly suburban school district in northern Utah. The Participant Selection Questionnaire (PSQ) was developed based on specific criteria that allowed us to select teachers who were as similar as possible with respect to their previous school-based, science-related experiences as well as nearly identical current school demographic characteristics, district structures, and policies. Working from the data provided by the PSQ, the criterionbased selection (LeCompte \& Preissle, 1993) was based on similarities in a number of personal characteristics (including analogous education backgrounds, similar teaching experience, and comparable efforts to devote a significant amount of time to science instruction in their classrooms (at least 30-45 minutes, 3 days a week), as well as similar student demographic characteristics of the schools in which they currently work (including ethnicity, socioeconomic status, and special education needs). District structures and policies were assumed to be identical because the teachers were selected from the same school district.

Inasmuch as we were also using the National Science Education Standards (NRC, 1996) as an analytical tool with which to observe and categorize classroom practice, it was also necessary to select teachers who were familiar with the current emphases in science education: inquiry-based instruction that actively engages students, integrates science and technology with other areas of the curriculum, and helps students construct meanings that are relevant to their daily lives. Therefore, after narrowing the potential population of participants through the selection survey, informal telephone interviews were conducted. These conversations focused on the potential participants' familiarity with reform documents and current trends in science education, as well as participation in local or national science-related teacher development experiences. Again, these requirements for participant selection were necessary to examine interactions between the externally imposed aspects of each school-based context (in this article, the tools of reform) and each teacher's beliefs as well as how this interchange influenced each teacher's interpretation and enactment of current science education reforms.

The Teachers. At the time of the study, Vicki (a pseudonym) taught 30 sixth-graders in a selfcontained classroom at Midway Elementary (a pseudonym), a large, suburban elementary school (approximately 700 students) with a predominantly white $(80 \%)$, middle-class population of students. As a fourth year teacher, Vicki was responsible to teach all areas of the regular elementary curriculum, including science (which she taught four times a week in 45-minute periods). Having served as the grade level science specialist during her first 3 years of teaching (teaching science to all 90 of the sixth graders at Midway), science held an important place in Vicki's curriculum, and she maintained that it was an essential part of each student's education. Selected as a member of a committee of educators involved in revising the Utah State Science Core Curriculum (USOE, 2002) over the 2 years prior to the study, Vicki was also familiar with the goals of the national reform movement, said she found them "difficult" to enact, but stated that she was making some effort to change her practice by adding more "variety" to her instruction (VFI5/14, p. 10).

Hannah (a pseudonym) had been teaching for 5 years at the time of the study as a member of a team of fifth-grade teachers at Parkway Elementary (a pseudonym). Like Midway Elementary, Parkway was a large elementary school (approximately 675 students) located just 12 miles from Midway. Because of their proximity within the same school district, the schools were similar in terms of demographics. In contrast to the sixth grade teachers at Midway, however, Hannah's colleagues had elected to departmentalize within grade level. This means that in addition to teaching a majority of the regular elementary curriculum to her class of 30 students, Hannah assumed the role of grade level science specialist, teaching science to each of the four fifth-grade 
classes in the school in 30-minute rotations four times each week (approximately 120 students). Additionally, Hannah acted as the science implementor in her school, serving as a resource to other teachers and representing Parkway Elementary at district-sponsored science meetings. Through this assignment, she had also become more familiar with the changes promoted by national reformers and enthusiastically tried to engage her students "in science instruction that is reflective of these practices" (HII, 3/8).

\section{Data Collection}

Multiple fieldwork strategies were used to gather data from which to describe these teachers, their beliefs, and their practice in a "case study format" (Wolcott, 1992, p. 37). These data collection strategies included: (a) questionnaires, (b) daily classroom observations of each of the two elementary teacher's science instruction over a 5-month time period, (c) formal and informal interviews and conversations with the key participants throughout the research (which continued electronically for 3 months after classroom observations were completed), (d) site administrator interviews, (e) other faculty member interviews, and (f) teacher- and studentproduced artifacts.

Questionnaires. The participants were asked to complete three, short questionnaires at the outset of the study, each used to access a quick overview of the participants' (a) science background, teacher education background, and experience teaching science; (b) beliefs about science; and (c) beliefs about science instruction. These data helped shape subsequent interviews and observations. The first of these instruments, the PSQ (mentioned previously), asked for specific information about the participants' college preparation, history of teacher development activities with a science emphasis, number of years of teaching experience, and time devoted to science instruction in their classrooms. The second instrument, the Teacher Beliefs about Science Questionnaire (TBQ), was a paper-and-pencil questionnaire that consisted of three questions aimed at constructing an understanding of these elementary teachers" "views" concerning the nature of science (see Abell \& Smith, 1994) and their familiarity with the current efforts to reform science education. The third instrument, the Teacher Instructional Practices Questionnaire (TIQ), was a two-page, multiple-choice measure that was adapted (with permission) from the Missouri Science Teacher Survey 2000 (see Moulding, 2001). This measure posed questions about the teachers' instructional practices, including goals for science instruction, methods of delivering science content, assessment strategies, use and availability of materials and other resources, and familiarity and use of state curricula and national science standards.

Observations. In case study investigation one of the major data gathering techniques is participant observation (Gall et al., 2003). In this study, inferences about teachers' beliefs required the examination of the instructional setting and the practices characteristic of the teachers (Thompson, 1992). Equal time was spent in both Vicki's and Hannah's classrooms between January and May for classroom observations of two complete science units. The observations began with 2 weeks of full-day observations in each classroom, including classroom instruction, breaks for lunch and recess, faculty meetings, preparation times before and after school, and so forth. After these initial weeks, observations were limited to the scheduled time each teacher devoted to science during each day and week (Hannah-4 days per week, 30-minute sessions for each of the four fifth-grade classes of students; Vicki-4 days per week, 45-minute sessions for her 
class only). All observations were recorded in field notes. Classroom observations were also videotaped for later reference and data analysis.

Interviews. Although we had many opportunities to listen to participants share their thoughts and experiences as part of multiple informal conversations, other events, ideas, and perceptions were accessed through more formal interviews. Scheduled every 2-4 weeks during the study, these conversations lasted 45 minutes to 2 hours. The protocol for each of these interviews emphasized a particular area of inquiry associated with the individual's experience with science or science teaching and learning. The first two of these conversations focused on beliefs about science and science instruction, emphasizing aspects of each teacher's teaching context and how these environmental elements impacted practice. The third probed the individual's science autobiography or life history related to science, including both in-school and out-of-school experiences. This conversation was followed by two additional interviews aimed at exploring these prior experiences and their relationship to beliefs and practice in greater depth. All formal interviews were audio taped and later transcribed.

Each participant was also asked to react to various hypothetical incidences about situations or events in science teaching. Instead of asking the teachers direct questions about their beliefs during these conversations, interviews about instances, or IAIs, provided a means of probing their knowledge or beliefs more deeply or more accurately (Southerland, Smith, \& Cummins, 2000). Nott and Wellington (1998) refer to these probes as "critical incidences" and define a critical incident as "an event which involves some kind of explanation of a scientific enterprise" (p. 581). They explain that "part of the incidents' criticality is that they evoke responses from the teacher which provide an insight into the teachers' view of science as well as matters to do with teaching and learning" (p. 582). Critical incidences that were rooted in classroom experience prompted these teachers to talk about their beliefs about science instruction. For the purposes of this study, we asked the participants to react to critical incidences or hypothetical classroom situations based on prior interviews or observations of these teachers' practice.

\section{Data Analysis}

Meaning was constructed using a constant comparative method of analysis (Strauss \& Corbin, 1990). In utilizing this approach, informal analysis began with the first observations and interviews and occurred daily throughout the research process. After reading and rereading the transcripts and field notes and reviewing the videotaped classroom observations, emergent patterns or trends were identified, coded, and linked to representative quotes or incidences. These themes or "recurring regularities" (see Guba, 1978) were first identified separately for each participant. The two cases were later compared in a cross-case analysis and common themes were identified and described.

To ensure the rigor and validity of analysis, data sources were triangulated and an active search for confirming and disconfirming evidence was made. The discovery of negative instances often led to new dialogue with participants in an effort to clarify the inconsistency in a process not unlike participant verification or member checking (Gall et al., 2003). These conversations consistently resulted in deeper understandings of the teachers' thinking, and seemingly disparate actions or words were clarified, often strengthening or supporting the developing theme. At other times, or in addition to the processes just described, where data appeared to disagree with a particular interpretation, specific interview transcripts, videotaped observations, and/or field notes were reexamined in an effort to discover the best explanation for the phenomenon. By using 
these options individually or in combination, all interpretations of the data were tested and verified.

\section{System of Notation}

Because multiple data sources were used to construct meaning in this study, it may be somewhat difficult for the reader to follow the findings notations in the following section. To clarify the system used for notation, a couple of examples are offered here so the reader can more easily determine the data source. An example of a source taken from a questionnaire might be (HTIQ, p. 2). H indicates that the information came from Hannah, TIQ identifies the questionnaire $(T I Q=$ Teacher Instructional Practices Questionnaire, PSQ $=$ Participant Selection Questionnaire, or TBQ $=$ Teacher Beliefs about Science Questionnaire), and p. 2 specifies the page number of the questionnaire from which the quote or example has been cited. An example of a notation from an interview might be (VFI4/18, p. 7). V indicates that Vicki was the source of the information, FI identifies the type of interview $(\mathrm{FI}=$ Formal Interview, II = Informal Interview $)$, $4 / 18$ is the date of the interview, and p. 7 indicates the page number of the transcribed interview. Other data sources that were used in the presentation of the data were noted as follows: $\mathrm{O}=$ Classroom Observation, $\mathrm{EC}=$ Electronic Communication.

\section{Findings}

After spending nearly 10 months interacting with the participants of this study, it became clear that there were a variety of internally constructed and externally imposed contextual forces at various levels that influenced both Hannah's and Vicki's thinking about teaching and learning science and their science instruction. Of these factors, the externally imposed contextual elements that emanated from district, state, and national reform efforts (the tools of reform) had varying effects on what happened in these teachers' classrooms. At the same time, because Vicki and Hannah held differing personal practical theories or fundamental beliefs about science and what it means to teach and learn science, they responded in distinctive ways to the messages they received from these external forces.

\section{National Science Education Standards}

Although the emphasis in science education at the national level focuses on a vision of reform, conversations with teachers at the local level indicated that many teachers were unaware of the scope of the organized national effort to change the way science is taught. In fact, during statesponsored summer workshops designed to improve science instruction (unrelated to the current study), grade 3 and grade 6 teachers were asked to respond in writing to questions about their familiarity with national science standards, local and national efforts to change the way science is taught at the elementary level, and what this new way of teaching science might look like (L.K. Smith, unpublished manuscript). Overwhelmingly, teachers stated that they were completely unfamiliar with the National Science Education Standards (NRC, 1996) or any other nationally disseminated reform document or agenda. Moreover, they claimed no knowledge of any organized national efforts to help them think differently about science instruction. Local efforts (either through state or district teacher development workshops or programs such as the one they were attending) to encourage a more "hands-on approach" to science (as the teachers understood it) were acknowledged, although notions of an inquiry-based approach to instruction in connection 
with district or state expectations were only rarely mentioned. Any remote familiarity with inquiry was most often tied to experiences in university courses and, occasionally, connected to attendance at conferences sponsored by the National Science Teachers Association. Overall, fewer than $5 \%$ of the teachers professed a comfortable knowledge of the standards documents and the reform messages represented within them (L. K. Smith, unpublished manuscript).

Because the participants of the study were selected based, in part, on their professed familiarity with either the messages of reform or the reform documents, we recognize that they may not appear to be representative of typical elementary teachers who might not claim any familiarity with the tools or messages of reform, as suggested from the survey described above. However, although both participants declared that they had some knowledge of the National Science Education Standards (NRC, 1996) and the Benchmarks for Science Literacy (AAAS, 1993), having "browsed through or read parts of them" (HTIQ, p. 2; VTIQ, p. 2), these documents apparently contributed little to Vicki's or Hannah's day-to-day thinking about science instruction. Indeed, neither teacher possessed a personal copy of the Standards, they were not aware that the documents could be easily accessed online, nor were the reform documents a source to which either teacher "referred routinely" or even "occasionally" in "planning curriculum, instruction, or assessment" (HTIQ, p. 2; VTIQ, p. 2).

Vicki and The Standards. Although Vicki had been exposed to "an inductive approach to teaching science during [her teacher preparation] program" (VFI4/18, p. 7), her introduction and single interaction with the standards documents and their connection to notions of inquiry-based science instruction came as a result of her involvement in revising the Utah State Science Core Curriculum (USOE, 1994, 2002). Selected as a member of a team of classroom teachers, state science specialists, and university science educators, Vicki spent an intense summer week working to rewrite/revise the science curriculum for sixth grade. The goal of the revision, Vicki explained, was to better align the state elementary core curricula with the National Science Education Standards (NRC, 1996) the Benchmarks for Science Literacy (AAAS, 1993), and Science for All Americans (AAAS, 1990), documents that Vicki "browsed through briefly" (VTIQ2, p. 2). To successfully revise the curriculum to support the standards, the state curriculum director and others - "someone from the university, and a guy from California who had done a lot of work on California's science core" (VFI4/18, pp. 16-17)-explained the importance of "intended learning outcomes" (ILOs) as a means of encouraging teachers to think differently about the way they teach science. During the week, time was also devoted to developing an understanding of "inquiry as described in the standards" (VFI4/18, p. 17), a way of teaching science that was, as Vicki described it, "new and interesting ... but a challenge [to implement]" (VFI3/2, p. 6). She voiced surprise that so much focus was placed on this "inquiry approach to science education" (VFI4/18, p. 17), which is a central emphasis of the reform agenda. "It was incredible," laughed Vicki. "We spent something like four hours [looking at information on] overhead [transparencies] trying to get to a real definition of inquiry!" (VFI4/18, p. 17).

Ultimately, the reform messages that Vicki took with her from her week's work at the state office of education enabled her to successfully negotiate the discourse of the national reform tools. Moreover, unlike teachers who use the language and assign to it understandings that do not align with the tenets of reform (Gregoire, 2003), Vicki clearly understood much of the primary intent of the standards documents. She explained that the standards require teachers to do something different from what they have done in the past. "They want children to experience more 'hands-on science.' Students shouldn't be sitting there looking at a picture in a book, doing science at a backed off perspective" (VFI4/18, p. 17). Beyond more hands-on, Vicki described this new way 
of teaching science as "helping kids to discover on their own" (VFI5/11, p. 5). Teachers should "design activities that will teach science concepts, but the students then have to make sense of it themselves" (VFI5/11, p. 6). She understood that teachers enacting reform are to "pose questions for students to answer" and "try to help children question the world around them" (VFI4/18, p. 18), "look at things in new ways, make mistakes, use higher order thinking skills, [and] have more flexibility in their thinking" (VFI6/11, p. 5). Eventually, she explained, teachers would then need to help children "ask and answer their own questions-really question the world around them and find answers to the questions they pose" (VFI4/18, p. 18). Clearly, Vicki understood that reformers call for teachers to actively engage students in scientific inquiry, much like the "multifaceted" (NRC, 1996, p. 23) activities in which scientists are engaged. Moreover, she understood that while "conducting hands-on science activities does not guarantee inquiry" (NRC, p. 23), inquiry-based instruction, as described in standards documents, includes the "diverse ways in which scientists study the natural world" (p. 23). She recognized that the call is for an emphasis on both the physical processes of investigation (e.g., observation, measurement) as well as the intellectual activities required for scientific exploration:

Inquiry is a multifaceted activity that involves observations; posing questions; examining books and other sources of information to see what is already known; planning investigations... using tools to gather, analyze, and interpret data; proposing answers, explanations, and predictions; and communicating the results. (NRC, 1996)

Despite her experience focusing on standards, benchmarks, and an overarching vision of inquiry-based science instruction in revising the science curriculum, Vicki admitted that she had not since referred to the national standards materials or documents (VFI5/14, p. 12) and, in fact, felt justified in not doing so. She insisted that "no teacher is ever really going to read them. It's just not realistic" (italics her emphasis, VFI4/18, p. 17), and cited three reasons for her assertion: first, she explained, teachers do not know of the existence of the reform documents (an assertion that is supported by the responses we received to our queries during summer workshops). "I certainly didn't know about them," she smiled. "I didn't realize that there were national standards. I knew that there was something like a national council of science, like there's a national council of reading and math and all, but I didn't realize they had actually published standards" (italics her emphasis, VFI5/14, p. 12). Second, Vicki suggested that teachers are "too busy and don't have the time to read such things" (VFI4/18, p. 17). Besides, she added, these national standards documents are not even specifically cited in the Utah State Science Core Curriculum (USOE, 2002) so "it is probably not really important for teachers to be familiar with them anyway" (VFI4/ 18, p. 18). (Please note that our examination indicated that the state curriculum did, in fact, cite the standards documents.) Finally, Vicki concluded, "I think that teachers depend on the state to include everything we need in the Core. And I know they have tried to take all the national stuff and make it what they really want. So, I haven't really worried about national standards too much" (VFI5/14, p. 12). "The Core is very specific. I read that and attend to that very carefully" (VFI4/ 18, p. 18). "I hope the people who wrote the Core have taken care to address the national standards for me. I consider that to be their job" (VFI5/14, p. 12).

Although Vicki told us that she had "become very interested in the 'inquiry' approach to science education" and said that she "would like to involve [her] students more in making their own observations and finding conclusions rather than forcing one "scientific method", (VTBQ, p. 1), her practice did not appear to be strongly influenced by standards documents and would likely not be described as reform-based. Indeed, a large majority of the science lessons in Vicki's classroom emphasized science content found only in the textbook and involved the students in 
individual or group work in which they were asked to complete worksheets, participate in teacherled discussions surrounding content from either the text or related videos, or respond in writing to questions from assigned texts (VO5/13, pp. 1-2). Most lessons focused on one major science concept related to an organized unit of study and began with a brief review of content from previous lessons (either through class discussion or a written quiz). These short assessments were followed by a lecture or teacher-led discussion in which "questions and answers [were] guided by the teacher's knowledge of science to ensure correct understanding of concepts" (VTIQ, p. 1). Most often, the discussion or lecture was based on information found in the textbook, using the text as a core or outline. Finally, Vicki's typical science period culminated in one of various written evaluations of students' understanding of the science concept discussed during the lesson. This assessment might have been a worksheet, written summary, or questions from the textbook (VO4/ 17, pp. 1-2). Occasionally (three times during one of the 5-week science units we observed), lessons included hands-on activities "in which the students followed detailed procedures that led them to discover science concepts or, more often, served to verify science concepts while following clearly defined procedures" (VTIQ, p. 1). Vicki explained that she inserted these activities as a way of adding "variety" to her teaching (VFI5/14, p. 10)—as "a motivational technique" (VFI6/11, p. 9) -rather than intentionally attempting to teach the content in new or different ways.

Vicki recognized that she did not use an inquiry-based (or "inductive") approach in teaching science. In fact, although she acknowledged that there are likely benefits to students-making learning "memorable," "motivating," and "enjoyable" (VFI6/11, p. 6), and even "forcing [students] to use higher level thinking skills ... and placing more responsibility for their learning on them rather than the teacher" (italics her emphasis, VFI6/11, p. 5)—she doubted that inquiry leads to real learning of science content. "I know the process is valuable, but I'm afraid they won't come up with the right answers. I'm concerned with them getting the right answer and then moving on, so I just give it to them" (italics her emphasis, VFI6/11, p. 6). "I've got to give them the facts. At some point science isn't just playing on the floor anymore. They need to know certain, basic facts .... They have to be told" (italics her emphasis, VFI6/11, p. 7). Moreover, Vicki found implementing inquiry to be "challenging" (VFI6/11, p. 5), even "intimidating" (VFI5/14, p. 8):

Inquiry activities are probably valuable, but they're so hard to do .... It's so hard to make those things up. And it's so hard to get them to run the way you think they should .... It's so hard to manage .... It's so hard for me because I don't think that way. I really struggle with that. I'm very linear. I want things done in the right order.... They're very hard for me to plan. If somebody else has an activity, I can probably try it. But I can't think it all up on my own. (italics her emphasis, VFI6/11, p. 5)

Understanding that she did not implement the standards as they are described in reform documents was just a bit troubling to Vicki, although her practice clearly reflected deeply held beliefs about what science is and about teaching and learning science that were contrary to those espoused by reformers. These beliefs were grounded in her notions about how she comes to know science (see Smith, 2005):

My first year [teaching] I wanted to close my door and not let anybody know what I was doing because I was teaching the way I learned best and how I thought my kids were going to learn best. And we were having a good time. But if somebody would have seen me teach, they probably would have thought that I was a bad teacher because I wasn't doing all of this wild, cutesy, get on the floor stuff. (italics added, VFI5/14, p. 8) 
Her disquiet on this point revealed the depth of contradiction in her thinking: although she readily outlined the potential advantages of implementing an inquiry-based approach to science instruction, her actual practice reflected a more traditional, expository approach. Despite her acknowledgement that inquiry might lead to student growth and increased motivation (VI6/11, pp. 9-10), she favored lecturing, reading, and discussing information from the textbook, completing worksheets, and implementing other teacher-centered teaching/learning strategies (VFI5/14, pp. 14-15, see also VFI6/11, pp. 6-7; VO4/17, pp. 1-2, and others). These methodologies reflected not only how she believed she learns-her "learning style" (VFI 4/18, p. 7)—but what she believed science to be (a "body of knowledge" [VFI5/14, p. 6]): "I like lecture. I like classes where I can sit and listen to someone talk; I learn very well that way and I like that about science, that there's factual knowledge that I can just memorize" (VFI 4/18, p. 5).

At the same time, Vicki firmly believed that her approach to science instruction was most beneficial to students, although "using the textbook and doing worksheets isn't, perhaps, [the students' favorite]. In fact," she smiled weakly, "I know it's one of their least favorite things to do. But I also think there's value to it. I really believe they benefit from it" (VFI5/14, p. 15). They benefited, Vicki explained, because "having fun playing with stuff for awhile" does not teach science concepts (VFI4/18, p. 7). Eventually, she argued,

... you have to get to the point. You can't just have manipulatives to play with all day. [The students] will never get the concept. You have to give them the scientific principle behind it. You've got to cover the content. You've got to give them the information. Otherwise, they will never really learn the science! (italics her emphasis, VFI5/14, p. 5)

Vicki believed that she must tell students what they need to know because she sincerely doubted that the inquiry process would work.

Hannah and The Standards. Hannah had had even less focused interaction with standards documents than Vicki. Although, like Vicki, she had been exposed to the notion of "inquiry learning" in college, Hannah "did not receive specific examples or training. It was more of a 'buzz' word that would pop up occasionally" (HEC7/2). Hannah related that she knew nothing of science standards when she began teaching. However, during her first teaching assignment she was assigned to be the school science implementor. In this capacity, she attended meetings with the district science specialist; served as a resource for other teachers in the school; and disseminated information about curricula, policy, and teacher development opportunities related to science education that she received through the district office (HII4/9, p. 1). It was during one of the monthly implementor meetings that the district science specialist introduced the standards documents to Hannah and the other attendees and they had the opportunity to "browse through/ read parts of them" (HTIQ, p. 2). This brief introduction was the only direct interaction she had had with these reform tools, although it is important to note that this brief introduction was more than most other teachers had reported in the Participant Selection Questionnaire.

Although Hannah had had minimal direct interface with The National Science Education Standards (NRC, 1996), the Benchmarks for Science Literacy (AAAS, 1993), or Science for All Americans (AAAS, 1990) documents, she was familiar with inquiry-based instruction as a way to effectively teach science to children. In addition to the initial introduction she had had during her science methods course, Hannah "received more information on inquiry-based learning at NSTA [National Science Teachers Association] conferences, through science implementor meetings, and by visiting with [the district science specialist]" (HEC7/2). Moreover, she noted that the "current emphasis on inquiry-based science learning is not new to science education" (HTBQ, 
p. 1). She cited "John Dewey and other scholars" for their work in promoting inquiry as a way to teach science and other disciplines: "I really enjoyed [reading] some of the writings and philosophies of Dewey in college. In many ways he was a pioneer in inquiry learning" (HEC7/2).

Not only was Hannah familiar with inquiry-based instruction, she clearly held basic beliefs about science and science teaching and learning that closely align with those promoted within the reform documents. As she asserted, understanding the intent of the tools of reform simply "reinforced some of my pre-existing beliefs" (HEC7/2): "Inquiry learning, by nature, is something that seems to fit well into my teaching style and philosophy-something that I buy into and believe in regardless of the current emphasis [in science education]" (HEC7/2). She believed that "children learn science by experiencing it: through asking questions, solving problems, investigating, making mistakes, and connecting science concepts to real life" (HEC8/9). Further, she explained that children need to "have a working understanding of basic concepts, such as cycles, and the basic vocabulary that goes with it" (HFI4/11, p. 1), but they also need to understand "basic processes: how to explore, how to discover, how to answer questions, how to experiment with things, how to observe, how to use and apply information. As part of science, these things are also important for them to learn" (HFI4/11, p. 1). In short, the tenets of reformbased practice were congruent with Hannah's fundamental beliefs about science and science teaching and learning.

These beliefs were also reflected in a practice that Hannah described as an attempt to "balance teaching science as a body of knowledge and teaching science as a way of looking at and understanding the world around us" (HEC7/2). Hannah's typical lessons encouraged students to take an active role in constructing their understanding of science concepts using science processes (e.g., observation, measurement, inference, communication, etc.). Each science lesson typically began with an initial, quick review of previously learned concepts followed by the body of the lesson, which took one of two forms: (a) a presentation or demonstration of new concepts and vocabulary, followed by a variety of learning activities (experiments, games, small-group discussions, written reports, drawings, presentations, jigsaw activities, art projects, debates, and others), or (b) an investigation based on either teacher-posed or student-initiated questions or problems (HO4/10, pp. 1-2 and others). Finally, virtually all science periods ended in what Hannah referred to as closure, a time when the students shared the results of their investigation or activity and Hannah guided them to reach an understanding of the science concepts they had explored (HO4/9, p. 2 and others). She stated, "I think it is important for students to discuss what they have discovered right after they have experienced it ....I feel that dialogue assists in the critical thinking processes so important in the learning of science" (HEC8/9). Clearly, it was not necessary for Hannah to alter her ways of thinking to meet the expectations of the National Science Education Standards (NRC, 1996). These were already notions to which she firmly ascribed.

\section{Core Curriculum and Related Testing}

Vicki's and Hannah's limited direct interface with national standards documents contrasted sharply with their marked familiarity with the state-mandated curriculum and corresponding endof-level assessment instrument. Both participants spoke freely and knowledgeably about the contents of these documents and agreed that the state science curriculum and correlated testing influenced their instructional decisions. The way the influence of these tools of reform played out for each teacher, however, differed and we argue that these differences are clearly grounded in dissimilar beliefs about teaching and learning science.

For both teachers, the curriculum dictated the basic science content that was taught in their classrooms. It provided "guidance" as to the "science topics and concepts that are appropriate for 
students at various grade levels" and was based on the Benchmarks for Science Literacy (AAAS, 1993) (VFI5/14, p. 6). The curriculum represented, in essence, a mandated content outline or framework for their science instruction (HFI6/4, p. 2; see also VFI5/14, p. 6), although both teachers suggested that they felt free to add material or content (as time and personal or student interest allowed) that was not directly addressed in the document. Additionally, both Hannah and Vicki suggested that having a statewide curriculum was a "good way to ensure that students are introduced to a variety of science topics throughout their schooling" (HFI6/4, p. 2); otherwise, students were likely to experience "the exact same science content, even, perhaps, the same learning activities" repeatedly over the course of their life in schools (VFI5/14, p. 6).

In contrast, the statewide, standardized criterion-referenced testing influenced Vicki's and Hannah's thinking about both content and pedagogy, although their individual responses to the assessment differed. Although both teachers felt pressured to "cover the material" because they and their students would be "held accountable for it" (VFI5/14, p. 1), the multiple-choice format and emphasis of the instrument sparked different reactions from the two teachers. For Hannah, the test introduced messages that markedly conflicted with those of science education reform because, she argued, "The test is designed to assess [students' knowledge of] isolated facts rather than broad or deep conceptual understanding" (HO\&II3/20, pp. 1-2). For Vicki, on the other hand, the format and content of the test reinforced her belief that her job was to "give [the students] a really good coverage of the [science] subjects and concepts in the core [curriculum], to present the factual material to them, to explain what they need to know" (VFI5/14, pp. 4-5).

Vicki, the State Core Curriculum, and End-of-Level Testing. Although Vicki referred to the state science curriculum as the single resource that "has had the greatest influence" on her science instruction (VTIQ, p. 1), this influence was clearly restricted to driving content rather than impacting her thinking about teaching science or her methods of instruction. Having worked under the direction of the state curriculum director to revise the state science curriculum "to make it content plus methodology" (work that resulted in brief descriptions of active, process-based teaching offered at the outset of the document), Vicki understood the intent of the revisions made to the state curriculum. However, despite these efforts, she still chose to describe the curriculum simply as "a list of topics" that she "needs to cover" (VFI6/11, p. 14). Despite the clear pedagogical objectives of the science specialists at the state level and her own personal involvement in developing the state standards, the state curriculum influenced what Vicki taught; it had done little to impact how she taught:

I know they're really trying to get inquiry skills into the Core.... They're trying to get these key words in there that will force teachers to teach [science] in a certain way and get them thinking in a new way. I understand what they're trying to do. But I don't know that putting the word "examine" instead of "identify" is going to make a difference. I know that they're trying to make it so that when you look at the Core you know what you're going to teach and how you're going to teach it. But $I$ still look at it, even though I was [involved in revising the curriculum], as a very specific list of topics. (italics her emphasis, VFI6/11, pp. 14-15).

Moreover, Vicki also assumed that other teachers throughout the state also viewed the state curriculum as a list of topics: "For too long teachers have looked at it as a list of things to teach" (VFI6/11, p. 14). Changing the language used in the curriculum, she argued, was not going to alter teachers' perceptions of the purpose of the document. Besides, for Vicki, teaching science content was what really mattered. 
In part, Vicki valued the state curriculum because "somebody has decided that these are the things that are important for children to understand" (VFI5/14, p. 1). Authoritative others, such as the state curriculum director and the other knowledgeable individuals responsible for the state curriculum, Vicki explained, appeared to adhere to national benchmarks and national content standards as they guided the development of the new state curriculum (VFI5/14, p. 12). Having browsed through these reform tools, Vicki trusted that the revised curriculum aligned closely with the national standards documents, at least in terms of science content. Accordingly, Vicki believed that teachers throughout the state (herself included) should be able to trust that strict adherence to the curriculum, as a list of science topics, was likely to ensure that teachers were teaching effectively and students were learning science. Again, even though Vicki understood that the state curriculum was intended to drive content and encourage particular instructional methodologies, she held fast to her beliefs that teaching science was fundamentally teaching a "body of knowledge" (VFI5/14, p. 6) and chose to ignore the messages about reenvisioning the way science is taught.

Vicki also noted that she understood the state curriculum to be a basic framework or outline of ideas that should be taught— "the core, not the whole apple" (VFI5/14, p. 6)—rather than a complete set of plans for teaching science to her sixth grade students. As such, it represented the minimum content related to the proscribed topics for each grade level. Therefore, although she made a concerted effort to "really try to cover the core, in depth enough that they really understand it, but not so much that it goes over [the students'] heads, because the students are going to be accountable for that and I'm going to be held accountable for that" (VFI5/14, p. 1), she purported that she felt comfortable adding to the content outlined in the curriculum and "trie[d] to flesh it out" by extending some of the concepts through additional classroom discussion or learning activities, or adding information that she believed was particularly relevant or interesting (VFI5/ 14, p. 6). Typically, as with most learning activities in Vicki's classroom, these extensions were presented as videos, worksheets, classroom lectures, discussions, or readings. Rarely, the additional instruction involved a demonstration or engaged students in a deductive, hands-on learning activity that reinforced information that Vicki had presented earlier.

The standardized criterion referenced test that she was required to administer to her students at the end of the school year also helped determine what Vicki chose to teach to students, and in some sense, her choice of instructional methodology. Public accountability was a real and sensitive issue for Vicki, and although she insisted that she was not "just trying to teach to the test" (VFI6/11, p. 7), being held accountable for teaching the students "the things that are on the tests" (VFI5/14, p. 6) profoundly impacted what she emphasized in class and shaped the instructional decisions she made. Because she felt that she needed to "get through a certain amount of information each day" (VFI6/11, p. 4), she also argued that she "lacks the time necessary to involve the students in activity-based learning, like hands-on learning or inquiry-based instruction." She was particularly troubled by the investment of time that was required for inquiry. It was problematic for her because it "takes so much time" (VFI5/14, p. 14). Lecture and discussion, on the other hand, enabled her to "give a lot more information" to her students in a shorter period of time (VFI6/11, p. 4). She was more confident that using these methods of instruction allowed her to cover the content necessary to enable her students to pass the test:

I've got to have the discussion/lecture because I've got to give [my students] the facts. They've got to know what they're supposed to be learning. They've got to understand certain things, especially because we have end-of-level tests. They need to know heat rises. They need to know light reflects. They have to be told. (VI6/11, p. 7, italics her emphasis) 
Inasmuch as she understood the end-of-level test to focus on science content (predominantly memorized facts and definitions) rather than a more reform-based emphasis on problem-solving and the processes of science, Vicki perceived that her favored methods of teaching science were reinforced as she considered how to "cover the information represented on the test" most efficiently and comprehensively (VFI6/11, p. 4). Because she focused on memorization of facts, Vicki perceived no trouble with the multiple-choice format of the tests, but complained about the choice of questions and the way individual questions were worded. Seemingly exasperated, she exclaimed, "It's just that the test doesn't match the Core! I could teach every single thing that's in that Core and my kids still wouldn't pass that science test because they just pick such tiny, nit-picky things to test!' As a result, Vicki believed that the tests were not a valuable means of informing her practice. Nevertheless, she used the assessment as a means of justifying her pedagogical choices. She explained that her rapid paced delivery was necessitated by the content coverage required for students to be best prepared for the end-of-year test.

At the time of this study, the tool of statewide science assessment was a complex one. Although the assessment was considered by its producers and the state science specialists to be conceptual in nature and to require student sense making of data, it was widely conceived of by teachers in the terms described by Vicki's "nit-picky things to test." This seeming contradiction was magnified by the secretive nature of the test, in which teachers could only gain a sense of the assessment from a handful of sample items. They were prevented from reviewing the full test itself (in an effort by administrators to prevent "teaching to the test").

Hannah, the State Core Curriculum, and End-of-Level Testing. Hannah agreed with Vicki's notion of authoritative "others" at the state level who should be responsible for ensuring that the state curriculum aligned with national content standards. (She did not refer to national science teaching standards.) "I go mostly by the State Core," she asserted, "I trust it to follow the national standards. I have so many other things to worry about, and I know that sounds irresponsible," Hannah smiled weakly, "but I just hope that "they' have taken care of that for me" (HFI4/11, p. 8).

Like Vicki, Hannah used the state-mandated science curriculum as a basic framework or outline for the science content she taught, although given a choice, she would not necessarily elect to teach the science topics outlined for her fifth grade students (HFI3/1, p. 9). She explained, "When I design my lessons at the beginning of the year, I make sure that there is a lesson or lessons to meet each standard. When I plan, I do make sure that every standard and objective is met" (HFI6/4, p. 1). However, she would have "liked having a little bit of freedom to go into more things that are interesting to me and the students" (HI3/1, p. 8). It was important, she argued, that teachers are passionate about what they teach. Thus, after ensuring that she has attended to each standard in the curriculum, she "supplements from there" and her "content is determined by level of interest to [her] and what [she] think[s] would be interesting and applicable to [her] students" (HFI4/11, p. 8). It is this extended or supplemented curriculum, she explained, that is the central emphasis of her instruction: "We all have our own philosophies about what we think is important to teach. I think those things will be emphasized no matter what the Core is" (HFI3/1, p. 9).

Unlike Vicki, however, Hannah did not view the state curriculum as the resource that has had the greatest impact on her science instruction. Instead, as she addressed the curriculum standards, Hannah emphasized that she focused on conceptual understanding rather than memorization of the "isolated facts" or "definitions" described for each standard and objective (HFI6/4, p. 2). She wanted her students to "have a broader, working understanding of basic concepts and themes in science, such as cycles" (HFI4/11, p. 1). As a result, Hannah suggested that going beyond the curriculum outlined by the state was necessary to accomplish her goals: 
If you stick to just exactly everything they need to know in the CoreCat that level—and don't take it a step further, [the students] don't see the everyday, real life application of the concepts I am trying to teach. Extensions are necessary to see that application-to broaden their knowledge base. Otherwise, science can easily become just a set of isolated facts. (HI6/4, p. 6)

Although the state curriculum influenced the science content taught in Hannah's classroom, she (like Vicki) explained that it contained "nothing that would affect the methodology" she chose to implement. Indeed, she was not aware of the intent of curriculum directors and others at the state level to infuse methodology into the curriculum through Intended Learning Outcomes (ILOs). "It definitely does not affect the way I teach," she declared (HFI6/4, p. 2). Instead, Hannah believed that her "teaching style and philosophy" had developed over time in response to a number of personal teaching/learning experiences in high school classes, college science courses, science methods courses, district science implementor meetings, and regional NSTA conferences (HEC7/2).

Also unlike Vicki, the end-of-level science assessment presented particular problems for Hannah, who argued that it matched neither the state curriculum nor the intent of the national standards documents, as she understood them. Although the core curriculum stressed concepts and processes, she explained, the national standards emphasized inquiry and problem solving. She understood that the test, in contrast to both of these reform tools, focused on vocabulary and isolated facts, things she did not emphasize in her science instruction."To teach the kids to be critical thinkers in science and then to give them a multiple choice test makes no sense!" she exclaimed (HFI3/1, p. 8). The messages she received from reform tools were conflicting, and therefore frustrating and confusing. As a result, she explained that the testing "constrains" (p. 8) her practice. She felt pressured to assess students differently than she believed was most appropriate throughout the year to accommodate the mandated testing:

A big frustration I have is that they tell us we should be teaching science with hands-on, and inquiry, and higher-level thinking. But then they test the way they do. I prefer to ask students to solve problems and to relate the concepts to real life situations-to encourage them to apply the knowledge they have gained. But they have to get used to the way the tests are set up. So I try to mix the way I test so the students are familiar with the format and being tested that way, but I also ask the types of questions that really make them think. (HO3/20, p. 1)

Thus, Hannah compromised her fundamental philosophy of teaching science only enough to modify her assessment practices. In an effort to prepare her students to successfully complete the state-mandated test, she modified her instruction through the inclusion of a few multiple-choice questions on unit tests similar to those on the end-of-level assessment.

\section{Discussion}

Tyack and Cuban (1995) note that an examination of the history of educational reform in the United States suggests that "it is the rare reform that performs and persists according to plan. Even long-lasting reforms are not static but evolve in ways often not foreseen by their proponents" (p. 60). Other scholars concur (Gregoire, 2003), maintaining that although reforms may alter schools and schooling, practitioners almost always modify reforms-sometimes through ambivalence and other times through outright hostility. In a similar way, although the teachers 
in this study were familiar with and reacted to specific tools of science education reform (i.e., standards, mandated curriculum, and end-of-level tests), these tools failed to encourage and support the kind of instruction envisioned by reformers. Instead, the response was to consciously choose to embrace, alter, or ignore reform messages.

Our data suggest that there are two interrelated explanations for this mixed response to science education reform and the tools used to promote it. The first explanation, which supports previous research (Laplante, 1997), is that the pedagogical and curricular decisions made by these teachers are solidly grounded in their beliefs about appropriate practice, beliefs that do not necessarily align with the tenets of current reform. Not surprisingly, these deeply held personal theories have not been easy to supplant, nor have they been readily modified (see Pajares, 1992) by ideas and methodologies that were externally imposed. Rather, these teachers' fundamental beliefs about science and their personal theories of what it means to teach and learn science have profoundly impacted the way they have interpreted reforms as well as how (or if) changes have been enacted in their classrooms.

The second explanation for Vicki's and Hannah's response to reform, which is equally critical and is a particular focus of this study, is that these teachers have experienced substantial uncertainty and frustration concerning the messages that have been communicated through different reform tools. Rather than promoting the enactment of reform and supporting these teachers' efforts to do so, the images of science teaching and learning that have been conveyed through these tools have been confusing, even contradictory. Because of this, Vicki and Hannah have lacked a clear understanding of what was required of them and voiced frustrations with what they perceived as inconsistencies or conflicting expectations.

The messages of the national standards documents, the state core curriculum, and the end-oflevel tests (three features of context that are often offered as potential tools used to promote educational reform) were understood by these two teachers to be inconsistent across each other. The result was that each teacher negotiated the tensions introduced by the conflicting messages in different ways based on her own personal theories. Clearly, neither of these teachers believed that the image of science teaching - as portrayed in the national reforms - was reflected in the core curriculum or the standardized tests that were designed to support the curriculum. For Hannah, who sought to teach science in a conceptually derived, inquiry-based format as described in the national standards, the tension was that the state-mandated core curriculum failed to provide clear and consistent pedagogical support for her instructional choices. At the same time, the curriculum introduced the need for a fast pace in teaching, a pace that made an inquiry oriented classroom difficult, but not impossible, to achieve. Additionally, the associated criterion-referenced test, which was understood by both teachers to serve as an accountability tool for content coverage, was also in direct contrast to Hannah's preferred pedagogical choices. In contrast, these same contextual elements posed far less of a problem for Vicki because she had elected to dismiss many of the tenets of the national reforms. Despite her work with the intended pedagogical message of the state curriculum (a message she personally rejected), for example, Vicki was comforted with the overwhelming interpretation of the state core as a content list; because other teachers perceived the core in only content terms, Vicki could as well. Moreover, the notion that the core curriculum was a vast list of science topics and concepts that must be covered supported Vicki's beliefs that science instruction requires rapid-paced transmission of knowledge, discouraging the implementation of the more time-intensive inquiry-based methodologies suggested by the national standards.

Our data also suggest that teachers may understand the messages of reform, but elect to disregard the proposed changes in terms of their own practice. This finding contrasts with trends found in previous research, which posit that teachers may unintentionally modify reform 
messages to fit their existing beliefs about science and science instruction while believing that they are implementing reforms as described by reformers (Gregoire, 2003). Vicki understood and openly acknowledged that she did not enact the instructional practices as suggested by reform initiatives. Nevertheless, she did not perceive this as a problem or a weakness in her practice. Instead, she defended her pedagogical choices, arguing that the current reforms represent merely a trend in science education that will likely change within a relatively short period of time (VFI6/11, pp. 10-11). She firmly believed that the specific, limited changes she had chosen to implement (variety in her teaching to help motivate students) were those that best served her students. These were modifications that she believed to be best suited to her students' needs, a belief that was based on her personal perceptions of her own needs as a learner. In essence, she intentionally reshaped the world in her own image, even as she felt just a bit defensive of what she did. It was not that her practice did not reflect reform messages because she did not understand them. Instead, Vicki clearly understood and could articulate the goals of reform; she simply chose not to embrace them. Thus, despite her familiarity with the national conversation, national messages of reform had done little to shape her beliefs or her practice. At the same time, the state messages, as embodied in the state curriculum and statewide assessment, actually served to support Vicki's personal approach to science teaching.

In contrast, Hannah enthusiastically engaged her students in reform-based science instruction (activity-based, inquiry-oriented learning activities). However, her sole formal impetus for these practices came from long ago methods courses; the other tools for reform were either silent for Hannah (national reforms), muted (core curriculum), or contradictory in their message (statewide assessments). Her choice to engage in reform-based practices was largely possible, however, because it did not require her to modify her beliefs about appropriate science instruction. Rather, understanding and adopting the methods and strategies promoted by reformers was a process of reconfirming and strengthening her deeply held beliefs about how children learn science-beliefs that were grounded in her perceptions of herself as a learner of science (see also Laplante, 1997). Because her fundamental beliefs about what is appropriate science instruction were originally more closely aligned with those of reforms, her teaching practices coincidentally corresponded to those described in the national conversation. Thus, although it might appear that she consciously elected to embrace the ideals described by reform initiatives, it could more accurately be understood to be a direct reflection of her own personal understanding and beliefs about learning and teaching science.

There has been considerable conversation about science curricula, assessment, science education reforms, and teachers' accountability for each. In reference to each of these issues, Yerrick, Parke, and Nugent (1997) wrote:

There are major forces which influence and often mandate how teachers will teach. School policies... strict accountability... rigorous state assessments are among them.... When teachers are faced with the pressures of school to cover the content in lockstep with their fellow science teachers... and when teachers see their name placed on an overhead projector in front of their peers to demonstrate that their students did not perform as well on standardized tests, then teachers will come to question the extra time and effort it takes to treat science differently. (p. 156)

This quote would make it seem as though teachers are driven to "see science differently," and that external forces work against this reenvisioning. However, our work suggests that the national "call to action" as embodied in the reforms is largely silent for the average classroom teacher. Moreover, the voice that seems to have the potential to most powerfully carry a message of reform, the state core curriculum, is perceived by the teachers as simply a description of content rather than 
a tool to help them envision new ways of teaching science. Given the unfortunate combination of a weak description of pedagogy and a voluminous list of science content, this reform tool is muted, or at best merely a whispered call for change. This situation is mirrored by teachers' response to the statewide-assessment, which, although it was intended to assess conceptual understanding, does so only in a limited fashion, emphasizing primarily the acquisition of isolated facts rather than broad conceptual understanding, the ability to problem-solve, or the processes of scientific investigation. This contradictory message is compounded by the secretive nature of the tool, leaving no means for teachers' preconceptions of it as a measure of rote knowledge to be disconfirmed. Again, this tool serves to silence the national message of reform, and, in light of the confusing and conflicting messages across the reform tools, the teachers in this study have ultimately chosen to remain true to their personal theories of appropriate practice, both despite and because of the external pressures imposed by the tools of reform.

\section{Implications}

What can these findings tell us? First, we must acknowledge the enormous role of personal practical theories, the internally constructed aspects of context, in shaping the practice of science teaching. Although the beliefs teachers hold are shaped by forces that are, to large degree, out of the direct influence of teacher educators (see Smith, 2005), it is clear that Hannah's teacher preparation and professional development experiences had had a profound impact on how she had come to view science teaching and learning. Through learning activities offered by thoughtful teacher educators, she had been exposed to new ways of thinking about science instruction which helped to shape her conceptions of her role as teacher. Later, these ideas influenced her selection and implementation of learning strategies and activities. Clearly, teacher educators have the responsibility to actively engage prospective and practicing teachers in inquiry learning activities in order to build an experiential grounding and solid understanding of what it means to teach and to learn inductively. Too often, teachers lack these kinds of experiences as learners of science, having been students in science classes that focused heavily on memorizing facts, without also emphasizing deeper conceptual understanding of subject matter (Cohen, McLaughlin, \& Talbert, 1993; Darling-Hammond \& McLaughlin, 1995) and inquiry as a means of learning science. Because teachers' pedagogical decisions are mediated by their perceptions of themselves as learners and knowers of science (see Laplante, 1997; Smith, 2005), this personal experience is critical to their understanding of and potential commitment to the tenets of reform. Additionally, thoughtful reflection might also be given by teacher educators to the selection of appropriate course readings that clearly describe the attributes, processes, and goals of inquiry. Such readings obviously had a positive effect on Hannah's thinking about herself as a teacher of science.

Second, recognizing the contradictory messages that teachers receive from indirect or limited exposure to the standards documents (AAAS, 1990, 1993; NRC, 1996) and the reform messages they contain, teacher educators at the university, state, and national levels must reconsider how they use these tools as a means of shaping prospective and inservice teachers' practice. One obvious role for teacher educators is to work directly with these externally imposed contextual features. Teacher professional development activities need to emphasize teachers' direct engagement with the actual description of reform as represented in reform documents (AAAS 1990, 1993; NRC, 1996, 2000). Teachers require scaffolded opportunities over time, with other teachers who are focusing on the same issues, and with the specific content they are teaching (see Garet, Porter, Desimone, Birman, \& Yoon, 2001) to directly wrestle with the messages of these documents and to work through the implications of these reforms for their own teaching practices. 
Moreover, this work must be with the primary documents, not derivations or interpretations of these texts.

Too, teacher educators striving to use the state and national reform documents to inform teachers' practice must be mindful of teachers' misconceptions about the nature of these documents themselves. It is important to recognize that teachers tend to perceive standards only in terms of content; they do not look to these documents for description of how that content should be taught. For the message of these tools to be heard, these misconceptions about curriculum standards must be explicitly dealt with in our work with teachers.

At the same time, state curriculum directors and others who influence local education policy need to consider the muted or contradictory messages teachers receive from different reform tools. If teachers are expected to reconsider how they think about teaching science, local support for their understanding and efforts is imperative. However, when curriculum intended to shape pedagogy and guide the selection of science content based on national standards and benchmarks is viewed merely as a list of topics, the messages of reform in state curricula are likely too implicit for the average classroom teacher. Furthermore, as has been described by many, state assessments need to be congruent with not only the content addressed in the national/state standards, but measures must be congruent with the pedagogy promoted by reform efforts as well. This need is obvious and often discussed (i.e., Yerrick, et al., 1997). But beyond that, state coordinators and science educators must make a systematic comparison between these assessments and the pedagogy advocated in the reforms, and make those comparisons again the centerpieces of discussions of teaching (Saka, 2006). Without clear descriptions of how statewide assessments compare to the goals of reform, teachers' will again perceive the assessments merely as measures of accountability for content coverage. This could only serve to diminish the importance of these potentially important tools for reform and unwittingly, and perhaps inappropriately, turn such assessments into barriers to reform.

These two case studies demonstrate that as teachers strive to negotiate the complex terrain imposed by reform and the conflicting messages found across the tools that are introduced to promote and support reform, they rely upon their own previously held conceptions of what it means to learn science and how they themselves learn science for guidance just as they rely on their own conceptions of the role of state standards and standardized assessments. Thus, internally constructed beliefs and conceptions play a pivotal role in shaping these teachers' reaction to the tools of reform, overriding the externally imposed aspects of context in shaping their pedagogical choices.

\section{References}

Abell, S.K., \& Smith, D.C. (1994). What is science?: Preservice elementary teachers' conceptions of the nature of science. International Journal of Science Education, 16, 475-487.

Alexander, P.A., \& Dochy, F.J. (1995). Conceptions of knowledge and beliefs: A comparison across varying cultural and educational communities. American Educational Research Journal, 32, 413-442.

American Association for the Advancement of Science (AAAS). (1990). Science for all Americans: Project 2061. New York: Oxford University Press.

American Association for the Advancement of Science (AAAS). (1993). Benchmarks for science literacy. New York: Oxford University Press.

Atkin, J.M., \& Black, P. (2003). Inside science education reform: A history of curricular and policy change. NewYork: Teachers College Press. 
Battista, M.T. (1994). Teacher beliefs and the reform movement in mathematics education. Phi Delta Kappan, 73, 745-752.

Bogdan, R.C., \& Biklen, S.K. (1998). Qualitative research for education: An introduction to theory and methods (3rd ed.). Boston: Allyn and Bacon.

Borko, H., Davinroy, K.H., Bliem, C.L., \& Cumbo, K.B. (2000). Exploring and supporting teacher change: Two third-grade teachers' experiences in a mathematics and literacy staff development project. Elementary School Journal, 100, 273-306.

Brickhouse, N., \& Bodner, G.M. (1992). The beginning science teacher: Classroom narratives of convictions and constraints. Journal of Research in Science Teaching, 29, 471-485.

Bullough, R.V., \& Baughman, K. (1997). "First-year teacher" eight years later: An inquiry into teacher development. New York: Teachers' College Press.

Bybee, R.W. (1993). Reforming science education: Social perspectives and personal reflections. New York: Teachers College Press.

Bybee, R.W. (1997). Achieving scientific literacy: From purposes to practices. Portsmouth, NE: Heinemann.

Calderhead, J., \& Robson, M. (1991). Images of teaching: Student teachers' early conceptions of classroom practice. Teaching and Teacher Education, 7, 1-8.

Clark, C.M., \& Peterson, P.L. (1986). Teachers' thought processes. In M.C. Wittrock (Ed.), Handbook of research on teaching (3rd ed., pp. 255-296). New York: Macmillan.

Cohen, D., \& Ball, D. (1990). Policy and practice: An overview. Educational Evaluation and Policy Analysis, 12, 233-239.

Cohen, D.K., McLaughlin, M.W., \& Talbert, J.E. (1993). Teaching for understanding: Challenges for policy and practice. San Francisco: Jossey-Bass.

Cooney, T.J., \& Shealy, B.E. (1997). On understanding the structure of teachers' beliefs and their relationship to change. In E. Fennema \& B.S. Nelson (Eds.), Mathematics teachers in transition (pp. 87-109). Mahwah, NJ: Erlbaum.

Cornett, J.W., Yeotis, C., \& Terwilliger, L. (1990). Teacher personal practical theories and their influence upon teacher curricular and instructional actions: A case study of a secondary science teacher. Science Education, 74, 59-70.

Crawford, B.A. (2000). Embracing the essence of inquiry: New roles for science teachers. Journal of Research in Science Teaching, 37, 916-937.

Cronin-Jones, L.L. (1991). Science teacher beliefs and their influence on curriculum implementation: Two case studies. Journal of Research in Science Teaching, 28, 235-250.

Cuban, L. (1990). Reforming again, again, and again. Educational Researcher, 19, 3-13.

Czerniak, C.M., Lumpe, A.T., \& Haney, J.J. (1999). Science teachers' beliefs and intentions to implement thematic units. Journal of Science Teacher Education, 10, 123-145.

Darling-Hammond, L., \& McLaughlin, M.W. (1995). Policies that support professional development in an era of reform. Phi Delta Kappan, 76, 597-604.

Davis, K.S. (2003). "Change is hard": What science teachers are telling us about reform and teacher learning in innovative practices. Science Education, 87, 3-30.

DeBoer, G.E. (1991). A history of ideas in science education: Implications for practice. New York: Teachers College Press.

Duncan, B., Gess-Newsome, J., \& Stoddart, T. (1993, April). Transformations of prior experiences and science methods into elementary classrooms. Paper presented at the Annual Meeting of the National Association for Research in Science Teaching, Atlanta.

Duschl, R.A. (1990). Restructuring science education: The importance of theories and their development. New York: Teachers College Press.

Duke, D. (2004). The challenges of educational change. Boston: Pearson Education, Inc. 
Franke, M.L., Carpenter, T., Fennema, E., Ansell, E., \& Behrend, J. (1998). Understanding teachers' self-sustaining, generative change in the context of professional development. Teaching and Teacher Education, 14, 67-80.

Fennema, E., \& Franke, M.L. (1992). Teachers' knowledge and its impact. In D.A. Grouws (Ed.), Handbook of research on mathematics teaching and learning (pp. 147-164). New York: Simon \& Schuster Macmillan.

Firestone, W.A., \& Louis, K.S. (1999). Schools as cultures. In J. Murphy \& K.S. Louis (Eds.), Handbook of research on educational administration (pp. 297-322). San Francisco: Jossey-Bass.

Fullan, M. (1993). Change forces: Probing the depths of educational reform. London: The Falmer Press.

Fullan, M.G., \& Stiegelbauer, S. (1991). The new meaning of educational change. New York: Teachers College Press.

Gall, M.D., Gall, J.P., \& Borg, W.R. (2003). Educational research: An introduction (7th ed.). Boston: Allyn and Bacon.

Garet, M.S., Porter, A.C., Desimone, L., Birman, B.F., \& Yoon, K.S. (2001). What makes professional development effective? Results from a national sample of teachers. American Educational Research Journal, 38, 915-945.

Gess-Newsome, J. (1999). Teachers' knowledge and beliefs about subject matter and its impact on instruction. In J. Gess-Newsome, \& N.G. Lederman (Eds.), Examining pedagogical content knowledge: The construct and its implications for science education (pp. 51-94). Dordrecht, The Netherlands: Kluwer Academic Publishers.

Gess-Newsome, J., Southerland, S. A., Johnston, A. \& Woodbury, S. (2003). Educational reform, personal practical theories, and dissatisfaction: The Anatomy of change in college science teaching. American Educational Research Journal, 40, 731-767.

Gregoire, M. (2003). Is it a challenge or a threat? A dual-process model of teachers' cognition and appraisal processes during conceptual change. Educational Psychology Review, 15, 147-179.

Guba, E.G. (1978). Toward a methodology of naturalistic inquiry in educational evaluation. Center for the Study of Evaluation. Los Angeles, CA: University of California.

Haney, J.J., Czerniak, C.M., \& Lumpe, A.T. (1996). Teacher beliefs and intentions regarding the implementation of science education reform strands. Journal of Research in Science Teaching, 33, 971-993.

Haney, J.J., \& Lumpe, A.T. (1995). A teacher professional development framework guided by reform policies, teachers' needs, and research. Journal of Science Teacher Education, 6, 187196.

Haney, J.J., \& McArthur, J. (2002). Four case studies of prospective science teachers' beliefs concerning constructivist teaching practices. Science Education, 86, 783-802.

Hargreaves, A. (1994). Changing teachers, changing times: Teachers' work and culture in the postmodern age. New York: Teachers College Press.

Holt-Reynolds, D. (1992). Personal history-based beliefs as relevant prior knowledge in course work. American Educational Research Journal, 29, 325-349.

International Reading Association. (2004). Standards for reading professionals. Newark, DE: International Reading Association.

Jacob, E. (1992). Culture, context, and cognition. In M.D. LeCompte, W.L. Millroy, \& J. Preissle (Eds.), The handbook of qualitative research in education (pp. 293-335). New York: Academic Press.

Jones, D. (1997). A conceptual framework for studying the relevance of context to mathematics teachers' change. In E. Fennema \& B.S. Nelson (Eds.), Mathematics teachers in transition (pp. 131-154). Mahwah, NJ: Erlbaum. 
Laplante, B. (1997). Teachers' beliefs and instructional strategies in science: Pushing analysis further. Science Education, 81, 277-294.

Lave, J. (1991). Situated learning. In L. Resnick, J. Levine, \& S. Teasley (Eds.), Perspectives on socially shared cognition (pp. 63-82). Washington, DC: American Psychological Association.

Lave, J. (1993). The practice of learning. In S. Chaiklin \& J. Lave (Eds.), Understanding practice: Perspectives on activity and context (pp. 3-32). Cambridge: Cambridge University Press.

LeCompte, M.D., \& Preissle, J. (1993). Ethnography and qualitative design in educational research (2nd ed.). San Diego, CA: Academic Press.

Lederman, N.G. (1992). Students' and teachers' conceptions of the nature of science: A review of the research. Journal of Research in Science Teaching, 29, 331-359.

Little, J. (1992). Teacher development and educational policy. In M. Fullan \& A. Hargreaves (Eds.), Teacher development and educational change (pp. 170-193). Bristol, PA: Falmer. Press.

Lortie, D. (1975). Schoolteacher: A sociological study. Chicago: University of Chicago

Loucks-Horsley, S., Kapitan, R., Carlson, M.D., Kuerbis, P.J., Clark, R.C., Melle, G.M., Sachse, T.P., \& Walton, E. (1990). Elementary school science for the 90s. Alexandria, VA: Association for Supervision and Curriculum Development.

Lumpe, A.T., Haney, J.J., \& Czerniak, C.M. (1998a). Science teacher beliefs and intentions to implement science-technology-society (STS) in the classroom. Journal of Science Teacher Education, 9, 1-24.

Lumpe, A.T., Haney, J.J., \& Czerniak, C.M. (1998b). Science teacher beliefs and intentions regarding the use of cooperative learning. School Science and Mathematics, 98, 123-132.

Lumpe, A.T., Haney, J.J., \& Czerniak, C.M. (2000). Assessing teachers' beliefs about their science teaching context. Journal of Research in Science Teaching, 37, 275-292.

Lynch, S. (2000). Equity and science education reform. Mahwah, NJ: Erlbaum.

McLaughlin, M.W. (1976). Implementation as mutual adaptation: Change in classroom organization. Teachers College Record, 77, 339-351.

McLaughlin, M.W. (1990). The Rand change agent study revisited: Macro perspectives and micro realities. Educational Researcher, 19, 11-16.

Moulding, L.R. (2001). Missouri science teacher survey 2000: Final results of statewide needs assessment. Jefferson City, MO: Missouri Department of Education.

National Council of Teachers of Mathematics. (2000). Principles and standards for school mathematics. Reston, VA: Author.

National Research Council. (1996). National science education standards. Washington, DC: National Academy Press.

Nott, M., \& Wellington, J. (1998). Eliciting, interpreting and developing teachers' understandings of the nature of science. Science and Education, 7, 579-594.

Pajares, M.F. (1992). Teachers' beliefs and educational research: Cleaning up a messy construct. Review of Educational Research, 62, 307-322.

Peshkin, A. (2000). The nature of interpretation in qualitative research. Educational Researcher, 29, 5-9.

Putnam, R.T., Heaton, R.M., Prawat, R.S., \& Remillard, J. (1992). Teaching mathematics for understanding: Discussing case studies of four fifth-grade teachers. The Elementary School Journal, 93, 213-229.

Raizen, S.A., \& Michelsohn, A.M. (1994). The future of science in elementary schools: Educating prospective teachers. San Francisco: Jossey-Bass. 
Richardson, V. (1996). The role of attitudes and beliefs in learning to teach. In J. Sikula (Ed.), Handbook of research on teacher education (pp. 102-119). New York: Simon \& Schuster Macmillan.

Saka, Y. (2006). What happens to our reform minded beginning science teachers? Unpublished doctoral dissertation, Florida State University, Tallahassee, Florida.

Sarrason, S.B. (1996). Revisiting "The culture of the school and the problem of change." New York: Teachers College Press.

Schwartz, R.S., Abd-El-Khalick, R., \& Lederman, N.G. (1999, January). An explanatory study of the "effectiveness" of elementary science specialists. Paper presented at the annual meeting of the Association for the Education of Teachers of Science, Austin, TX.

Smith, L.K. (2005). The impact of early life history on teachers' beliefs: In-school and out-ofschool experiences as learners and knowers of science. Teachers and Teaching: Theory and Practice, 11, 5-36.

Southerland, S.A., Gess-Newsome, J., \& Johnston, A. (2003). Portraying science in the classroom: How scientists' beliefs are manifested in classroom practice. Journal of Research in Science Teaching, 40, 669-691.

Southerland, S., Smith, M.U., \& Cummins, C.L. (2000). "What do you mean by that?” Using structured interviews to assess science understanding. In J.J. Mintzes, J.H. Wandersee, \& J.P. Novak (Eds.), Assessing science understanding: A human constructivist view (pp. 72-93). San Diego, CA: Academic Press.

Sprinthall, N.A., Reiman, A.J., \& Thies-Sprinthall, L. (1996). Teacher professional development. In J. Sikula (Ed.), Handbook of research on teacher education (pp. 666-703). New York: Simon \& Schuster Macmillan.

Strauss, A., \& Corbin, J. (1990). Basics of qualitative research: Grounded theory procedures and techniques. Newbury Park, CA: Sage Publications.

Sweeney, A.E., Bula, O.A., \& Cornett, J.W. (2001). The role of personal practice theories in the professional development of a beginning high school chemistry teacher. Journal of Research in Science Teaching, 38, 408-441.

Thompson, A.G. (1992). Teachers' beliefs and conceptions: A synthesis of the research. In D.A. Grouws (Ed.), Handbook of research on mathematics teaching and learning (pp. 127-146). New York: Simon \& Schuster Macmillan.

Tilgner, P.J. (1990). Avoiding science in the elementary school. Science Education, 74, 421431.

Tyack, D., \& Cuban, L. (1995). Tinkering toward utopia: A century of public school reform. Cambridge, MA: Harvard University Press.

Utah State Office of Education. (1994). Utah State Science Core Curriculum. Salt Lake City, UT: Author.

Utah State Office of Education. (2002). Utah State Science Core Curriculum. Salt Lake City, UT: Author.

Vesilind, E.M., \& Jones, M.G. (1998). Gardens or graveyards: Science education reform and school culture. Journal of Research in Science Teaching, 35, 757-775.

Warren, R.L. (1987). The school and its community context: The methodology of a field study. In G. Spindler (Ed.), Education and cultural process (pp. 120-135). Prospect Heights, IL: Waveland.

Windschitl, M. (2002). Framing constructivism in practice as the negotiation of dilemmas: An analysis of the conceptual, pedagogical, cultural, and political challenge facing teachers. Review of Educational Research, 72, 131-175. 
Wolcott, H.F. (1992). Posturing in qualitative inquiry. In M.D. LeCompte, W.L. Millroy, \& J. Preissle (Eds.), The handbook of qualitative research in education (pp. 3-52). New York: Academic Press.

Yager, R.E. (1992). Viewpoint: what we did not learn from the 60s about science curriculum reform. Journal of Research in Science Teaching, 29, 905-910.

Yee, G., \& Kirst, M. (1994). Lessons from the new science curriculum of the 1950s and 1960s. Education and Urban Society, 26, 158-171.

Yerrick, R., Parke, H., \& Nugent, J. (1997). Struggling to promote deeply rooted change: The "filtering effect" of teachers' beliefs on understanding transformational views of teaching science. Science Education, 81, 137-159. 